\title{
Removal of Volatile Organic Compounds Driven by Platinum Supported on Amorphous Phosphated Titanium Oxide
}

\author{
HUANG Xieyi ${ }^{1,2}$, WANG Peng ${ }^{2,3}$, YIN Guoheng ${ }^{1}$, ZHANG Shaoning ${ }^{1}$, \\ ZHAO Wei $^{1}$, WANG Dong ${ }^{1}$, BI Qingyuan ${ }^{1}$, HUANG Fuqiang ${ }^{1,3,4}$
}

(1. State Key Laboratory of High Performance Ceramics and Superfine Microstructure, Shanghai Institute of Ceramics, Chinese Academy of Sciences, Shanghai 200050, China; 2. University of Chinese Academy of Sciences, Beijing 100049, China; 3. School of Physical Science and Technology, ShanghaiTech University, Shanghai 200031, China; 4. State Key Laboratory of Rare Earth Materials Chemistry and Applications, College of Chemistry and Molecular Engineering, Peking University, Beijing 100871, China)

\begin{abstract}
Development of high efficiency catalyst is the key factor to catalytic combustion of volatile organic compounds (VOCs). Herein, amorphous mesoporous phosphated $\mathrm{TiO}_{2}$ (ATO-P) with high specific surface area supported platinum catalyst was successfully fabricated. P-dopant can increase the surface area (up to $278.9 \mathrm{~m}^{2} \cdot \mathrm{g}^{-1}$ ) of ATO-P, which is 21 times higher than that of pristine $\mathrm{TiO}_{2}$, and make the amorphous titanium oxide structure. The supported $\mathrm{Pt}$ catalyst with amorphous mesoporous feature shows impressive performance and excellent thermostability for VOCs oxidation. The Pt/ATO-P catalyst exhibits outstanding catalytic efficiency, the $T_{50}$ and $T_{90}$ (temperatures required for achieving conversions of $50 \%$ and $90 \%$ ) are respectively $130{ }^{\circ} \mathrm{C}$ and $140{ }^{\circ} \mathrm{C}$, for toluene oxidation under high gas hourly space velocity (GHSV) of $36000 \mathrm{~mL} \cdot \mathrm{h}^{-1} \cdot \mathrm{g}^{-1}$ and toluene concentration of $10000 \mathrm{~mL} \cdot \mathrm{m}^{-3}$. The performance is superior to the reference $\mathrm{Pt} / \mathrm{TiO}_{2}$ and comparable with the state-of-the-art catalysts. These findings can make a significant contribution on the new applications of amorphous mesoporous phosphated materials in VOCs removal.
\end{abstract}

Key words: amorphous mesoporous structure; phosphated $\mathrm{TiO}_{2}$; Pt nanoparticle; toluene oxidation; VOCs removal

Volatile organic compounds (VOCs), like toluene, benzene, esters and hydrocarbons, are emitted from various industrial sources which can cause serious environmental pollution and health problems ${ }^{[1-2]}$. Toluene, one kind of toxic and strong carcinogenic chemical, is frequently used in making paints, adhesives, rubbers, and leather tanning processes because of its excellent ability to dissolve organic substances ${ }^{[3-4]}$. However, toluene is difficult to degrade due to its stable structure ${ }^{[5]}$. Several techniques, such as physical and chemical adsorption, photocatalytic and catalytic oxidation methods, are widely used for the combustion of $\mathrm{VOCs}^{[6-7]}$. Among them, catalytic oxidation is regarded as a promising approach owing to its high efficiency and convenient operating conditions ${ }^{[8]}$.

Researches on catalysts for toluene oxidation have been conducted, including noble metal and metal oxides catalysts $^{[9-10]}$. Due to the significant reduction on activation energy during the catalytic oxidation process, noble metal based catalysts, such as $\mathrm{Pt}, \mathrm{Pd}, \mathrm{Au}, \mathrm{Rh}$, and $\mathrm{Ir}$ have shown impressive performance in toluene remo$\mathrm{val}^{[11-13]}$. It was found that supported Pt catalysts showed the best catalytic performance compared with other noble metals ${ }^{[14-15]}$. It should be pointed out that the supports play an important role in the catalytic reaction processes $^{[16-18]}$. Many works have focused on the metalsupport interaction by studying the catalytic properties of $\mathrm{TiO}_{2}, \mathrm{Al}_{2} \mathrm{O}_{3}, \mathrm{ZrO}_{2}$, and $\mathrm{ZnO}$ supported $\mathrm{Au}$ nanoparticles $^{[19]}$, and the shape effect of $\mathrm{Pt} / \mathrm{CeO}_{2}$ catalysts ${ }^{[10]}$. Nevertheless, most supports suffer from low specific surface area and few active sites, which are crucial for the overall catalytic activity.

\footnotetext{
Received date: 2019-04-12; Revised date: $2019-05-24$

Foundation item: National Key Research and Development Program of China (2016YFB0901600); National Natural Science Foundation of China (21872166); Science \& Technology Commission of Shanghai (16ZR1440400, 16JC1401700); The Key Research Program of Chinese Academy of Sciences (QYZDJ-SSW-JSC013 and KGZD-EW-T06)

Biography: Huang Xieyi (1994-), male, Master candidate. E-mail: huangxieyi@student.sic.ac.cn 黄谢意(1994-), 男, 硕士研究生. E-mail: huangxieyi@student.sic.ac.cn

Corresponding author: BI Qingyuan, associate professor. E-mail: biqingyuan@mail.sic.ac.cn; HUANG Fuqiang, professor. E-mail: huangfq@mail.sic.ac.cn 毕庆元, 副研究员. E-mail: huangfq@mail.sic.ac.cn; 黄富强, 研究员. E-mail: huangfq@mail.sic.ac.cn
} 
Due to high specific surface area and variable valence, amorphous materials have attracted increasing interests in VOCs oxidation. And the numerous defects in amorphous structures can offer large quantities of oxygen vacancies, which are beneficial for the adsorption of oxygen and organic molecules. Lee, et $a l^{[20]}$. reported that carbon black supported amorphous $\mathrm{MnO}_{x}$ is highly efficient for oxygen involved reaction. Wang, et al ${ }^{[21]}$ found that amorphous $\mathrm{MnO}_{x}$ modified $\mathrm{Co}_{3} \mathrm{O}_{4}$ can enhance the catalytic activity for the VOCs oxidation. It was demonstrated that the amorphous structure of bimetallic $\mathrm{Pd}-\mathrm{Pt} / \mathrm{CeO}_{2}-\mathrm{Al}_{2} \mathrm{O}_{3}-\mathrm{TiO}_{2}$ could provide more vacancies and active sites for catalytic combustion ${ }^{[22]}$. Therefore, the amorphous catalysts show a tremendous potential in practical catalytic reactions. However, it is still a challenge to develop highly active and robust catalysts based on the amorphous materials for the oxidation of VOCs.

Herein, we demonstrate an efficient Pt/ATO-P catalyst for the catalytic removal of VOCs under high gas hourly space velocity (GHSV) and high substrate concentration. It should be pointed out that incorporating phosphorus into the framework of $\mathrm{TiO}_{2}$ is a widely applied strategy for obtaining amorphous mesoporous feature ${ }^{[23-24]}$. And the $\mathrm{P}$ element can stabilize the $\mathrm{TiO}_{2}$ framework and significantly increase the specific surface area ${ }^{[24]}$.

\section{Experimental}

\subsection{Preparation of sample}

\subsubsection{Preparation of support}

All reagents were of analytical grade and were used without any purification. $3 \mathrm{~mL}$ of tetrabutyl titanate was dissolved in $30 \mathrm{~mL}$ of ethanol at room temperature, which was marked as solution A. Then $0.125 \mathrm{~mL}$ of phosphoric acid $\left(\mathrm{H}_{3} \mathrm{PO}_{4}\right)$ was subsequently dropwisely added into solution A with stirring to form a homogenous mixture, and kept stirring for $24 \mathrm{~h}$. The obtained white solid products were separated by centrifuge, and washed by deionized water and ethanol several times, followed by freeze drying overnight. The as-prepared products were calcined at $400{ }^{\circ} \mathrm{C}$ in air for $4 \mathrm{~h}$ at a heating rate of $5{ }^{\circ} \mathrm{C} \cdot \mathrm{min}^{-1}$.

\subsubsection{Preparation of catalyst}

The ATO-P supported platinum (Pt/ATO-P) sample was prepared via impregnation method. A desired amount of ATO-P was transferred into aqueous solution containing appropriate amount of chloroplatinic acid $\left(\mathrm{H}_{2} \mathrm{PtCl}_{4}\right)$. Subsequently, the samples were impregnated at room temperature for $12 \mathrm{~h}$. After drying out the $\mathrm{H}_{2} \mathrm{O}$ at $80{ }^{\circ} \mathrm{C}$, the samples were treated at $350{ }^{\circ} \mathrm{C}$ for $2 \mathrm{~h}$ with a $\mathrm{H}_{2} /$ Ar mixture $(5 / 95, V / V)$.

\subsection{Characterization}

XRD characterization of the samples was carried out on a German Bruker D8 Advance X-ray diffractometer (XRD) using the Ni-filtered $\mathrm{Cu} \mathrm{K} \alpha$ radiation at $40 \mathrm{kV}$ and $40 \mathrm{~mA}$. Nitrogen adsorption-desorption isotherms were measured at $-196{ }^{\circ} \mathrm{C}$ on a Micromeritics ASAP 2460 analyzer. Samples were degassed at $120{ }^{\circ} \mathrm{C}$ for $24 \mathrm{~h}$ prior to the measurement. The specific surface area of the samples was calculated using the Brunauer-EmmettTeller (BET) method with the adsorption data at the relative pressure $\left(p / p_{0}\right)$ range of $0.05-0.2$. The total pore volumes were estimated at $p / p_{0}=0.99$. The pore size distribution (PSD) curves were calculated from the adsorption branch using Barrett-Joyner-Halenda (BJH) model. The prepared materials were pressed into tablets with $\mathrm{KBr}$ powder and then detected by FT-IR (Perkin Elmer, USA) in the scanning range from 400 to $4000 \mathrm{~cm}^{-1}$. SEM images were obtained by Hitachi-S4800. A JEOL 2011 microscope operating at $200 \mathrm{kV}$ equipped with an EDX unit $(\mathrm{Si}(\mathrm{Li})$ detector) was used for the transmission electron microscope (TEM) and high resolution transmission electron microscope (HRTEM) investigations. The samples for TEM testing were prepared by dispersing the powder in ethanol and applying a drop of highly dilute suspension on carbon-coated grids. XPS data were recorded with a Perkin Elmer PHI 5000 C system equipped with a hemispherical electron energy analyzer. The spectrometer was operated at $15 \mathrm{kV}$ and $20 \mathrm{~mA}$, and a magnesium anode ( $\mathrm{Mg} \mathrm{K} \alpha, h v=1253.6 \mathrm{eV}$ ) was used. The $\mathrm{C} 1 \mathrm{~s}$ line $(284.6 \mathrm{eV})$ was used as the reference to calibrate the binding energies (BE). TG measurements were conducted on a Netzsch STA 449C TG-DSC thermoanalyzer. The flow rate of the carrier gas (air) was $30 \mathrm{~mL} \cdot \mathrm{min}^{-1}$. The temperature was raised from room temperature to $800{ }^{\circ} \mathrm{C}$ at a ramp rate of $10{ }^{\circ} \mathrm{C} \cdot \mathrm{min}^{-1}$. Prior to $\mathrm{H}_{2}$-TPR test, the sample $(100 \mathrm{mg})$ was pretreated at $200{ }^{\circ} \mathrm{C}$ for $2 \mathrm{~h}$ and cooled to $50{ }^{\circ} \mathrm{C}$ in the flowing He. TPR experiment was carried out in $5 \mathrm{vol} \% \mathrm{H}_{2} / \mathrm{He}$ flowing at $30 \mathrm{~mL} \cdot \mathrm{min}^{-1}$, with a ramping rate of $5{ }^{\circ} \mathrm{C} \cdot \mathrm{min}^{-1}$ to a final temperature of $c a .800{ }^{\circ} \mathrm{C}$. The signal was monitored using a TCD detector.

\subsection{Catalytic activity test}

The catalytic activity of samples was evaluated in a continued-flow fixed-bed quartz reactor with $50 \mathrm{mg}$ catalyst. Toluene was introduced into the reactor with bubbling toluene solution in ice bath with pure air. The concentration of toluene was about $10^{4} \mathrm{~mL} \cdot \mathrm{m}^{-3}$, and the flow rate was kept at $30 \mathrm{~mL} \cdot \mathrm{min}^{-1}$ by a mass controller, equivalent to a gas hour space velocity (GHSV) of $36000 \mathrm{~mL} \cdot \mathrm{h}^{-1} \cdot \mathrm{g}^{-1}$. After steady operation for $100 \mathrm{~min}$, the activity of the catalyst was tested. Toluene concen- 
tration was detected by a gas chromatograph equipped with a flame ionization detector. The toluene conversion ( $\left.X_{\text {toluene }}\right)$ was calculated according to the equation:

$$
X_{\text {toluene }}=\left(C_{\text {in }}-C_{\text {out }}\right) / C_{\text {in }} \cdot 100 \%
$$

where $C_{\text {in }}$ and $C_{\text {out }}$ are the inlet and outlet toluene concentrations, respectively.

\section{Results and discussion}

\subsection{Physicochemical properties of ATO-P support}

Fig. 1 displays the schematic diagram of amorphous ATO-P prepared via facile co-precipitation. XRD patterns of ATO-P and $\mathrm{TiO}_{2}$ are shown in Fig. 2. All diffraction peaks of basic $\mathrm{TiO}_{2}$ sample are indexed to anatase phase (JCPDS 21-1276). Interestingly, there is no $\mathrm{TiO}_{2}$ crystal phase observed for ATO-P sample (Fig. 2), suggesting that ATO-P sample is typically amorphous and phosphorus dopant can markedly restrain the crystallization of anatase ${ }^{[25-26]}$.

According to the TGA-DSC thermograms (Fig. 3), a thermal decomposition of ATO-P took place in the temperature range of $20-900{ }^{\circ} \mathrm{C}$. The first DSC peak at $30-80{ }^{\circ} \mathrm{C}$ is due to the release of physical adsorbed water. When all the water is released, $\mathrm{Ti}-\mathrm{OH}$ and $\mathrm{HPO}_{4}{ }^{2-}$

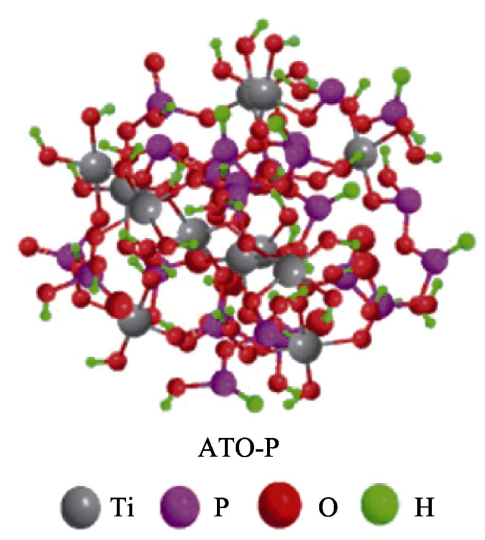

Fig. 1 Structure of amorphous ATO-P prepared via facile co-precipitation

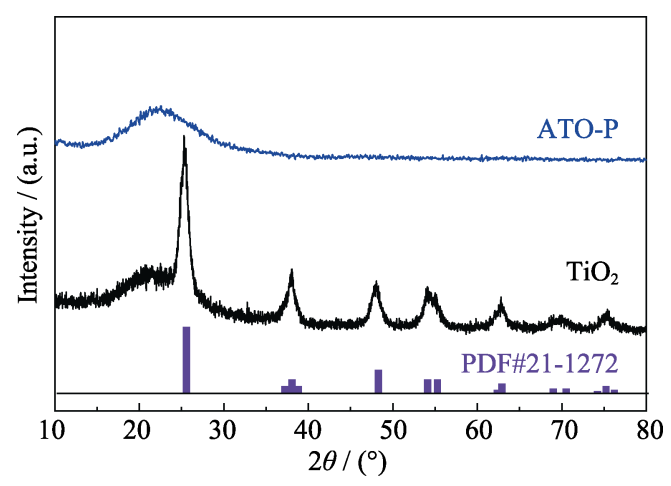

Fig. 2 XRD patterns of $\mathrm{TiO}_{2}$ and ATO-P samples

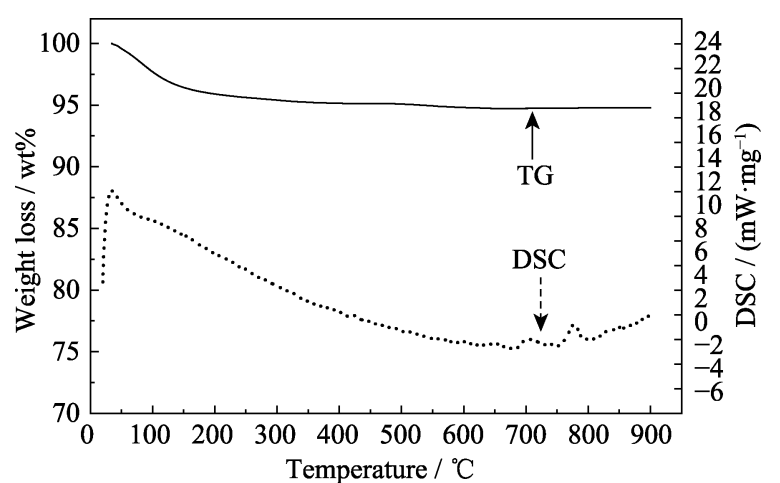

Fig. 3 TG (solid line) and DSC (dashed line) curves for ATO-P

groups start to condense ${ }^{[27]}$. These processes occur simultaneously in the temperature range of $100-220{ }^{\circ} \mathrm{C}$ $\left(1.927 \%\right.$ of weight loss) and $220-516^{\circ} \mathrm{C} \quad(0.7 \%$ of weight loss), resulting in an overlap of the TG data. There is no further weight loss up to $516{ }^{\circ} \mathrm{C}$. The DSC curve shows two exothermic peaks at 704 and $781{ }^{\circ} \mathrm{C}$, corresponding to a two-step exothermic transformation of ATO-P into a crystalline phase.

Fig. 4(a,b) show the SEM images of ATO-P. The ATO-P nanoparticles are homogeneously dispersed with the particle size of $\sim 20 \mathrm{~nm}$, and the sizes are similar to that of $\mathrm{TiO}_{2}$ (Fig. S1(a)). HRTEM was employed to characterize the nanostructure of samples. No porous structure is observed in the HRTEM image of $\mathrm{TiO}_{2}$ (Fig. S1(b)), while various porous structure is shown in ATO-P (Fig. 4(c)). Moreover, the pores of ATO-P are uniform, and the average diameter is around $10 \mathrm{~nm}$. EDS elemental mappings indicate that the $\mathrm{P}$ element homogeneously distributes in ATO-P (Fig. 4(d)). It is found that $\mathrm{H}_{3} \mathrm{PO}_{4}$ owns unique effects for synthesizing amorphous mesoporous phosphated $\mathrm{TiO}_{2}{ }^{[28-29]}$.
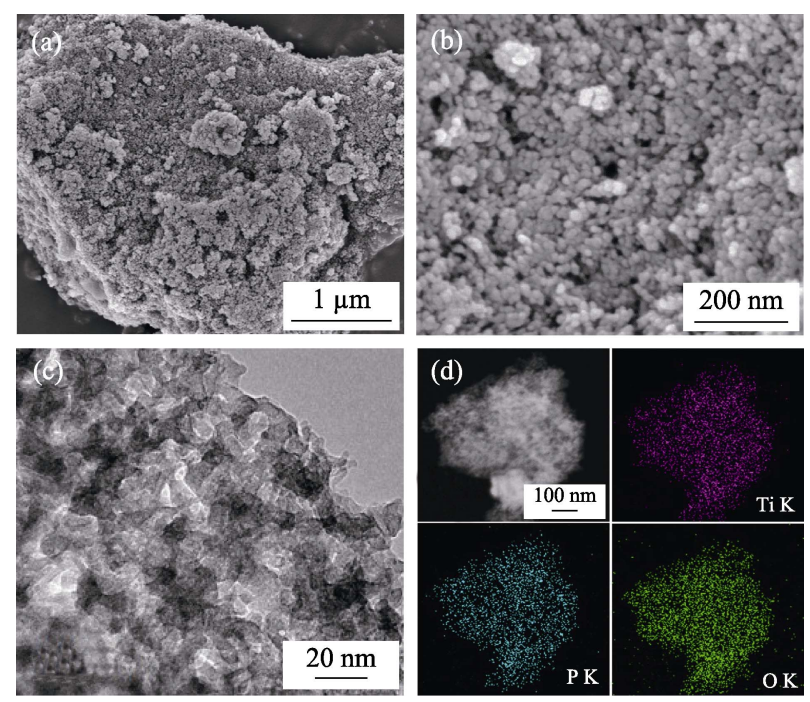

Fig. 4 SEM (a, b) and HRTEM (c) images, and EDS elemental mapping (d) of ATO-P 
As shown in Fig. 5, the obtained ATO-P sample shows a characteristic type-IV isotherm with clear hysteresis loop locates at the $p / p_{0}$ range of $0.45-1.0$, showing the existence of a large amount of mesopore. Notably, the specific surface area of $278.9 \mathrm{~m}^{2} \cdot \mathrm{g}^{-1}$ for ATO-P is 21 times higher than that of pristine $\mathrm{TiO}_{2}$. The pore diameters of ATO-P center around $10 \mathrm{~nm}$ (Fig. 5 and Table 1), which is consistent with HRTEM result (Fig. 4(c)).

The results of EDX are listed in Table 1. The actual P concentration is much less than the initial addition amount of $\mathrm{H}_{3} \mathrm{PO}_{4}$, suggesting that partial $\mathrm{H}_{3} \mathrm{PO}_{4}$ is leached during the preparation process.

FT-IR spectra of $\mathrm{TiO}_{2}$ and ATO-P samples are depicted in Fig. 6. The wide absorption bands around 3440 and $1620 \mathrm{~cm}^{-1}$ are attributed to the surface adsorbed water and/or hydroxyl groups ${ }^{[30-31]}$. The bands at $1100 \mathrm{~cm}^{-1}$ are ascribed to the stretching vibration of $\mathrm{Ti}-\mathrm{O}-\mathrm{P}$ species, which are absent in $\mathrm{TiO}_{2}$. The weak bands at $610 \mathrm{~cm}^{-1}$
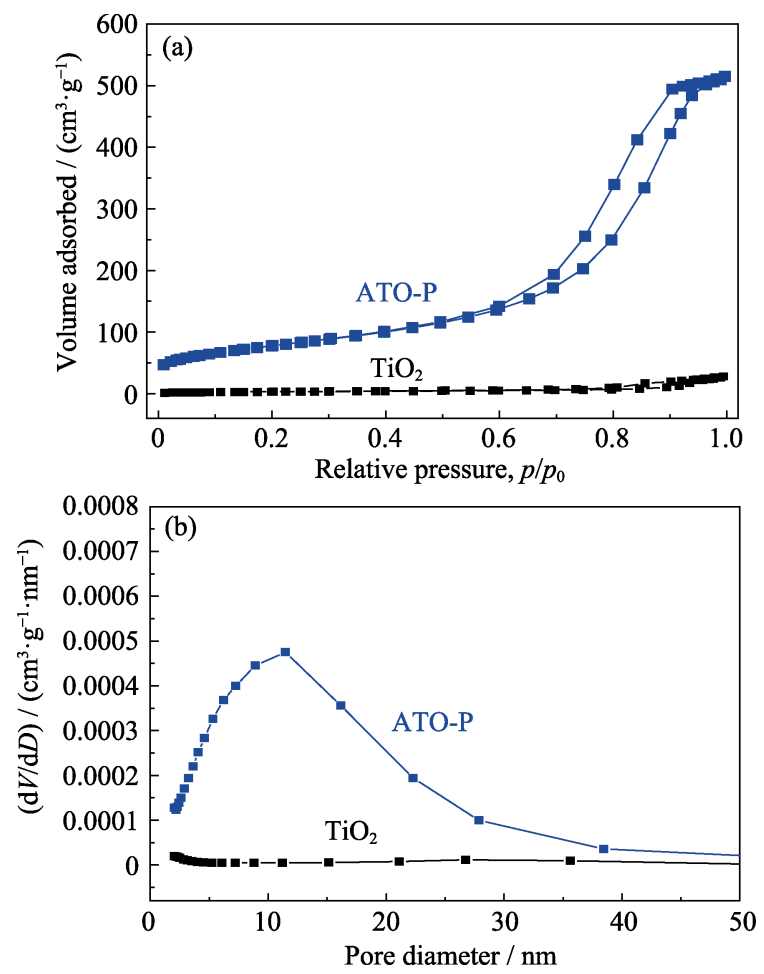

Fig. $5 \mathrm{~N}_{2}$ adsorption-desorption isotherms (a) and pore size distributions (b) of ATO-P and $\mathrm{TiO}_{2}$

Table 1 Textural properties and elemental compositions of $\mathrm{TiO}_{2}$ and ATO-P samples

\begin{tabular}{|c|c|c|c|c|c|c|}
\hline \multirow{2}{*}{ Catalyst } & \multirow{2}{*}{$\begin{array}{c}\text { BET } \\
\text { surface area } \\
/\left(\mathrm{m}^{2} \cdot \mathrm{g}^{-1}\right)\end{array}$} & \multirow{2}{*}{$\begin{array}{c}\text { Pore } \\
\text { volume } \\
/\left(\mathrm{cm}^{3} \cdot \mathrm{g}^{-1}\right)\end{array}$} & \multirow{2}{*}{$\begin{array}{l}\text { Pore size } \\
\text { /nm }\end{array}$} & \multicolumn{3}{|c|}{$\begin{array}{l}\text { Elemental composition } \\
\qquad / \mathrm{wt} \% \%^{[\mathrm{a}]}\end{array}$} \\
\hline & & & & $P$ & $\mathrm{Ti}$ & $\mathrm{O}$ \\
\hline $\mathrm{TiO}_{2}$ & 10.9 & 0.04 & 15.7 & - & 60.0 & 40.0 \\
\hline ATO-P & 278.9 & 0.80 & 11.4 & 19.2 & 32.1 & 48.7 \\
\hline
\end{tabular}

[a] Weight fraction ( $w t \%)$ are determined by EDX analysis

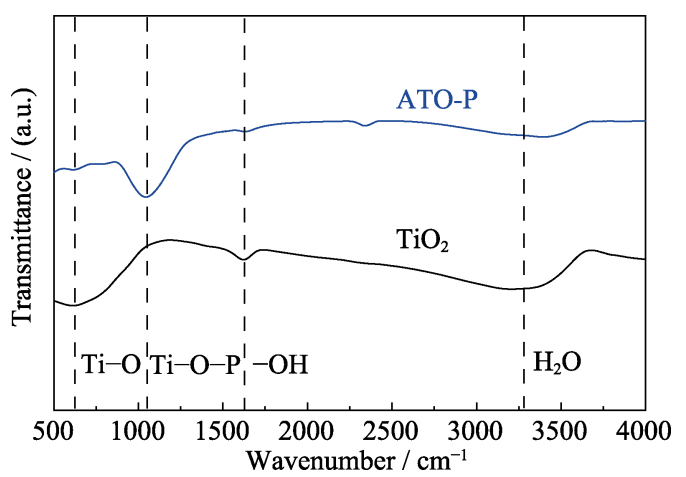

Fig. 6 FT-IR spectra of $\mathrm{TiO}_{2}$ and ATO-P

are due to the vibration of $\mathrm{Ti}-\mathrm{O}-\mathrm{Ti}$ bond ${ }^{[22]}$. Compared with $\mathrm{TiO}_{2}$, a weak peak appears in series ATO-P, which may result from the incorporating effect of phosphorus dopant. There is no distinct peak over the range of $700-800 \mathrm{~cm}^{-1}$ (Fig. 6), indicating the absence of $\mathrm{P}-\mathrm{O}-\mathrm{P}$ groups in the amorphous mesoporous phosphated $\mathrm{TiO}_{2}$. Therefore, the $\mathrm{P}$ element is incorporated into the frameworks of ATO-P by forming Ti-O-P bonds ${ }^{[24]}$.

As shown in Fig. 7(a), the full XPS spectra indicate the existence of $\mathrm{P}$ in ATO-P. High-resolution XPS spectra of $P 2 p$, Ti $2 p$ and $O 1$ s are depicted in Fig. 7(b-d). The peak of $\mathrm{P} 2 \mathrm{p}$ of ATO-P is at $134.0 \mathrm{eV}$, suggesting that phosphorus in ATO-P gives a pentavalent oxidation state of $\mathrm{P}^{5+}$. No peak observed at $128.6 \mathrm{eV}$, which is the characteristic binding energy of $\mathrm{P} 2 \mathrm{p}$ in TiP, indicating the absence of Ti-P bonds in ATO-P samples. As depicted in Fig. 7(c), the peaks of Ti2 $p_{3 / 2}$ and Ti2 $p_{1 / 2}$ in ATO-P show remarkable blue-shift owing to the incorporation effect of phosphorus element. Fig. 7(d) shows the XPS spectra of O1s signals of $\mathrm{TiO}_{2}$ and ATO-P. The single peak at $529.5 \mathrm{eV}$ is corresponded to the oxygen in $\mathrm{Ti}^{-} \mathrm{O}$ bond of $\mathrm{TiO}_{2}$. However, the O1s spectrum of ATO-P contains two peaks at 531.4 and $532.9 \mathrm{eV}$, which are contributed to $\mathrm{Ti}-\mathrm{O}-\mathrm{P}$ and $\mathrm{O}-\mathrm{H}$ bond, respectively ${ }^{[32-33]}$.

\subsection{Physicochemical properties of Pt/ATO-P catalysts}

Fig. 8(a) shows that the Pt nanoparticles are well dispersed over the ATO-P support, and the size is relatively uniform with the average parameter of $(1.8 \pm 0.3) \mathrm{nm}$ (insert in Fig. 8(a)). Fig. 8(b) and S2 demonstrate a $d$-spacing of $0.23 \mathrm{~nm}$, attributed to the (111) plane of the highly crystalline Pt nanostructure. Furthermore, the actual Pt content was also confirmed by inductively coulped plasma atomic emission spectra (ICP-AES). The mass loadings of $\mathrm{Pt}$ in $\mathrm{Pt} / \mathrm{TiO}_{2}$ and $\mathrm{Pt} / \mathrm{ATO}-\mathrm{P}$ catalysts are 0.90 and 0.92 , respectively, which are close to the nominal composition of $1 \mathrm{wt} \%$.

Fig. 8(c) shows the XRD patterns of Pt/ATO-P and $\mathrm{Pt} / \mathrm{TiO}_{2}$ catalysts. The amorphous structure is still remained 

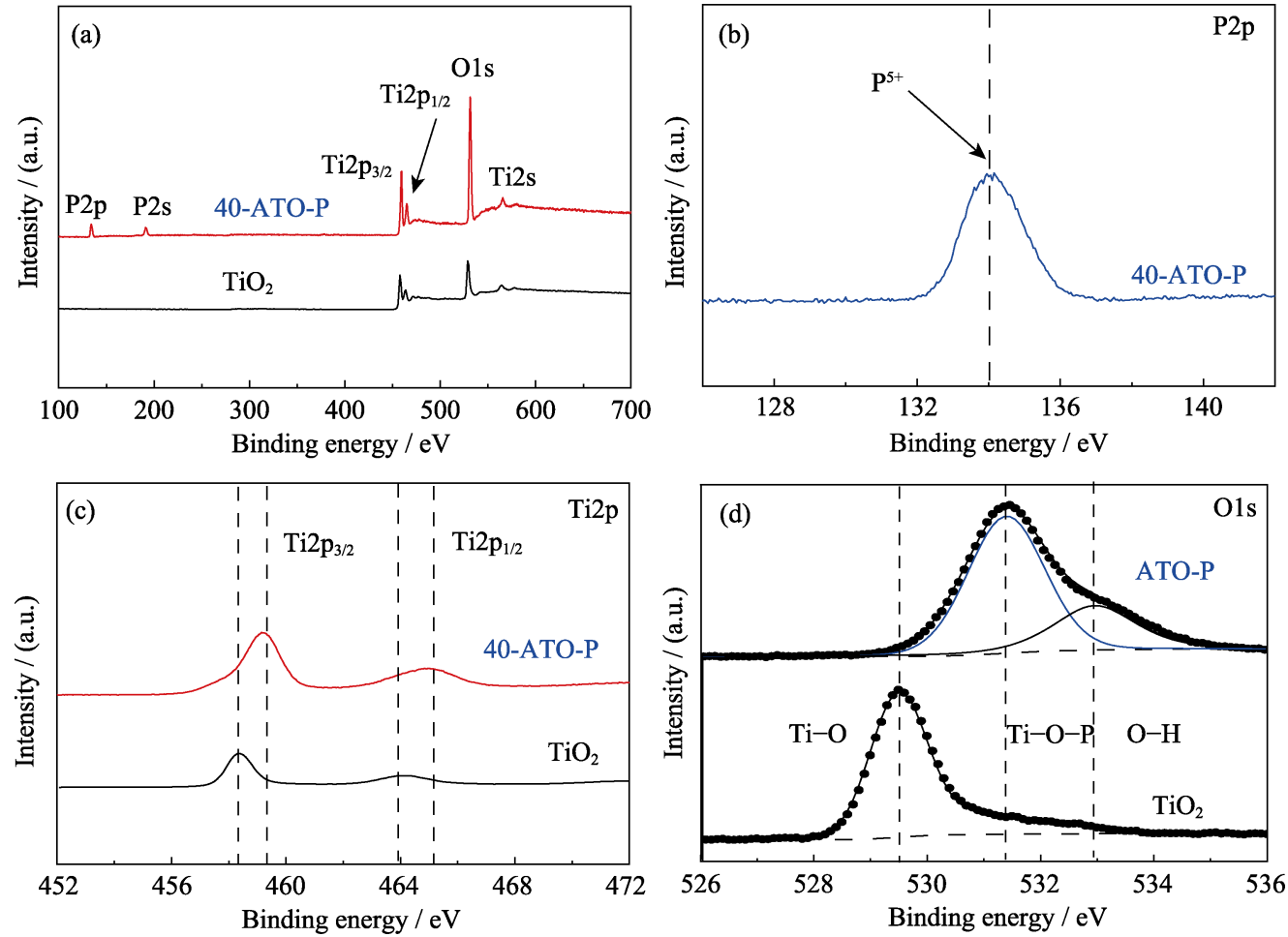

Fig. 7 Full XPS spectra (a) of $\mathrm{TiO}_{2}$ and ATO-P; High-resolution XPS P2p (b), Ti2p (c), and O1s (d) of TiO 2 and ATO-P
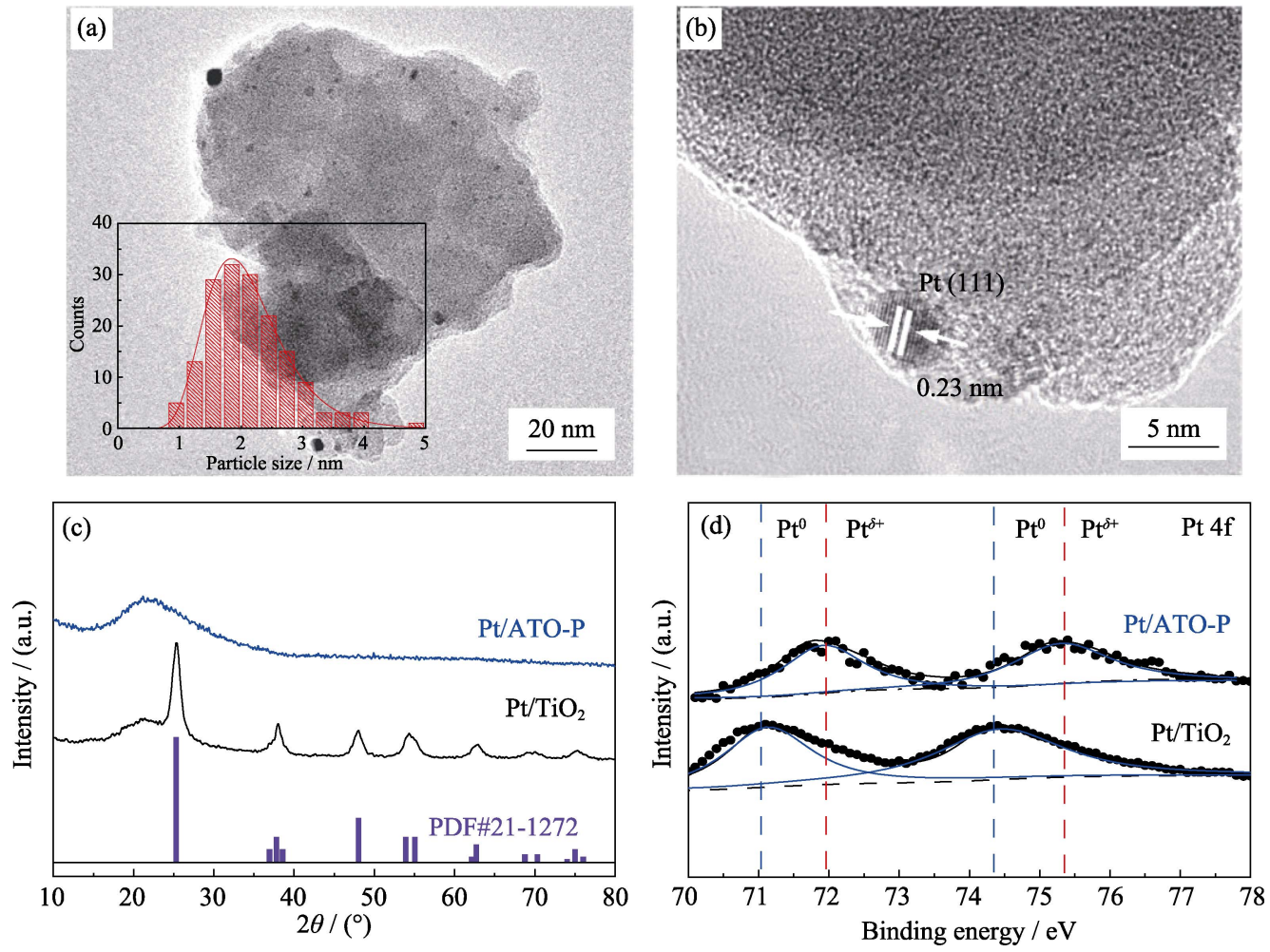

Fig. 8 TEM (a) and HRTEM (b) images of Pt/ATO-P with insert in (a) indicating the particle size distribution of Pt nanoparticles, XRD patterns (c) and XPS Pt4f (d) of Pt/ATO-P

for Pt/ATO-P sample. However, no diffraction pattern of $\mathrm{Pt}$ nanoparticles is observed, indicating that the $\mathrm{Pt}$ nanoparticles are quite small and/or the Pt species are highly dispersed on the ATO-P surface. These results are well consistent with the HRTEM data above mentioned in Fig. 8(a,b).

The results of XPS analysis of Pt/ATO-P and $\mathrm{Pt} / \mathrm{TiO}_{2}$ samples are depicted in Fig. 8(d). It is known that the positions of $\mathrm{Pt} \mathrm{f}_{7 / 2}$ binding energy at $71.1,72.4$, and $74.2 \mathrm{eV}$ are attributed to $\mathrm{Pt}^{0}, \mathrm{Pt}^{2+}$, and $\mathrm{Pt}^{4+}$ species, respec- 
tively ${ }^{[34]}$. Similiar XPS profiles are rendered as the indication of a mixture of various valence states for $\mathrm{Pt}$ species over the small Pt nanoparticles. The exisence of $\mathrm{Pt}^{\delta+}$ species reflects the strong metal-support interaction ( $\mathrm{Pt}-\mathrm{ATO}-\mathrm{P})$, especially the prominent electronic interaction between active $\mathrm{Pt}$ and underlying phosphated $\mathrm{TiO}_{2}$ support $^{[35]}$. This is probably due to the changes of the metalsupport interaction by doping phosphorus atoms which can make an obvious effect on $\mathrm{Ti}-\mathrm{O}-\mathrm{P}$ frameworks.

The $\mathrm{H}_{2}$-TPR profiles depicted in Fig. $\mathrm{S} 3$ show that there are two $\mathrm{H}_{2}$-consumption peaks at low and high temperature attributed to weak and strong interaction of $\mathrm{Pt}$ and supports, respectively ${ }^{[36]}$. Notably, two reduction peaks of Pt/ATO-P catalyst at 78 and $601{ }^{\circ} \mathrm{C}$ show stronger intensity than that of $\mathrm{Pt} / \mathrm{TiO}_{2}$ at 72 and $433{ }^{\circ} \mathrm{C}$, indicating strong Pt-support interaction for Pt/ATO-P. These results are consistent with the XPS data.

\subsection{Removal of VOCs by Pt/ATO-P catalysts}

The catalytic efficiencies are depicted in Fig. 9. It is clearly observed that reaction temperature can enhance the performance of Pt/ATO-P catalyst. The $T_{50}$ and $T_{90}$ are widely used to evaluate the catalytic performance ${ }^{[37]}$. As shown in Fig. 9(a), Pt/ATO-P shows the excellent catalytic activity. $T_{50}$ and $T_{90}$ values for toluene combustion are 130 and $140{ }^{\circ} \mathrm{C}$, which are much lower than those of Pt/TiO $/ \mathrm{Ti}_{2}$ with $T_{50}$ and $T_{90}$ of 160 and $190{ }^{\circ} \mathrm{C}$, respectively. Combined with the above XPS data (Fig. 8(d)),
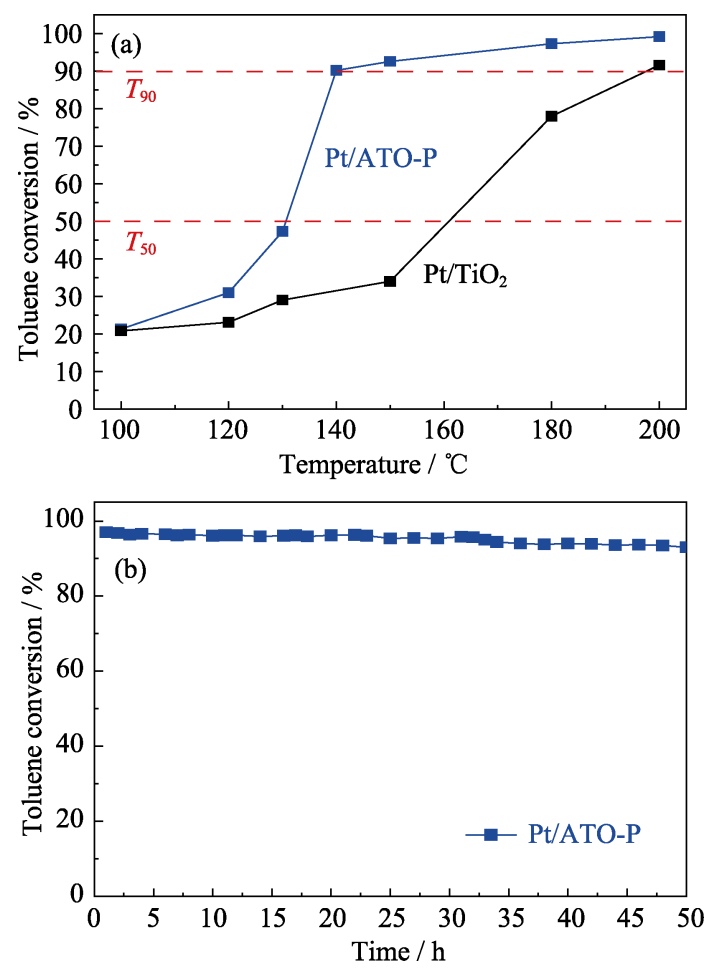

Fig. 9 Toluene conversion (a) of $1 \mathrm{wt} \% \mathrm{Pt} / \mathrm{ATO}-\mathrm{P}$ with respect to reaction temperature, and thermal stability (b) of Pt/ATO-P at $180{ }^{\circ} \mathrm{C}$ it can be concluded that the existance of phosphorus component plays an important role in electronic structure of the active Pt species underlying amorphous mesoporous ATO-P support and thus the catalytic oxidation removal of toluene over Pt/ATO-P catalyst.

It is well known that noble metal loading significantly affects the catalytic behavior for many reactions. Pt/ATO-P catalysts with different Pt loadings were examined, and the results are depicted in Fig. 10. Compared with $0.5 \mathrm{wt} \%$ and $2 \mathrm{wt} \%$, the Pt loading of $1 \mathrm{wt} \%$ shows better performance (lower $T_{50}$ and $T_{90}$ ) for toluene oxidation. The low catalytic activity of $0.5 \mathrm{wt} \%$ Pt/ATO-P results from low density of active platinum nanoparticles anchoring on the surface of ATO-P support. For the Pt/ATO-P catalyst with Pt loading up to $2 \mathrm{wt} \%$, larger size of Pt nanopartices $(\sim 5 \mathrm{~nm})$ can be obtained (Fig. S4). Larger Pt particles can not only decrease the dispersion of Pt species ${ }^{[38]}$, but also lead to a weaker metal-support (Pt/ATO-P) interactions, thus resulting in the poor activity.

Stability is critical for the catalysts on the practical application. $1 \mathrm{wt} \%$ Pt/ATO-P exhibits excellent thermal stability for toluene oxidation over a 50 -h period on stream at $180{ }^{\circ} \mathrm{C}$ without visible loss of activity, as shown in Fig. 9(b). The toluene conversion remains a high level of $95.4 \%$ at the end of reaction process and maintains near full selectivity to final products of $\mathrm{CO}_{2}$ and $\mathrm{H}_{2} \mathrm{O}$. The excellent stability of Pt/ATO-P catalyst is attributed to the unique geometric structure of crystalline Pt nanoparticles and amorphous mesoporous phosphated $\mathrm{TiO}_{2}$ with prominent electronic interaction. For the used $1 \mathrm{wt} \%$ Pt/ATO-P, TEM measurement and XPS analysis (Fig. S5 and Fig. S6) demonstrate no significant change on the morphology, average size of Pt nanoparticles, and the chemical oxidation state of active Pt species. These results suggest the robustness of Pt/ATO-P catalyst for toluene oxidation removal under a relatively mild thermal process.

Given the superb thermocatalytic performance for

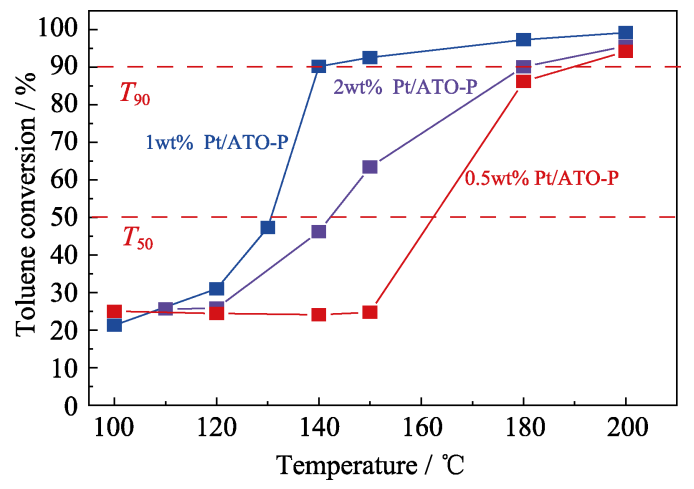

Fig. 10 Toluene conversion over Pt/ATO-P catalysts with different Pt loadings 

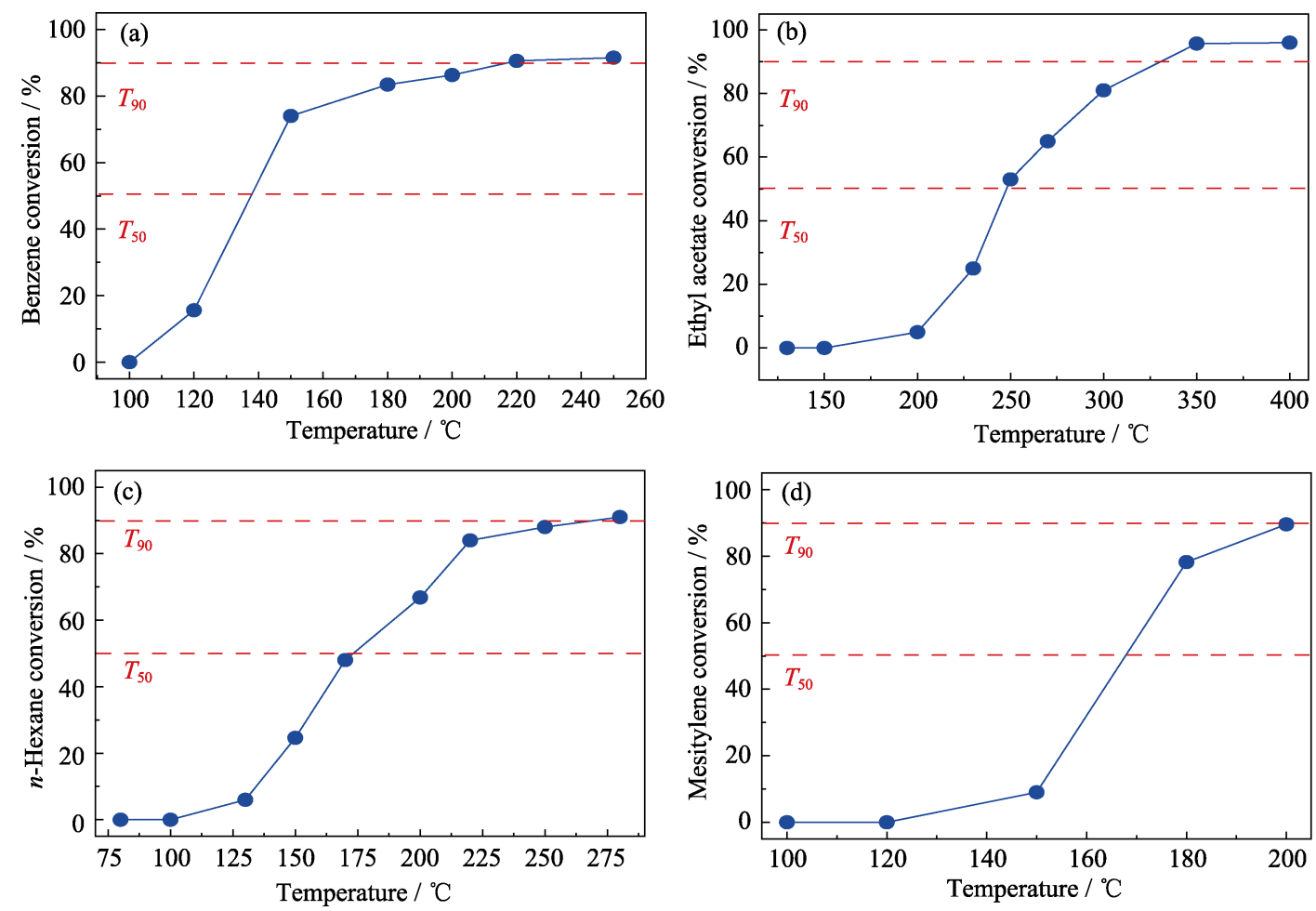

Fig. 11 Catalytic activity of Pt/ATO-P for the conversion of benzene (a), ethyl acetate (b), $n$-hexane (c), and mesitylene (d) with respect to reaction temperature

1wt\% Pt/ATO-P catalyst toward toluene oxidation, we were curious to examine whether the engineered material would also catalyze the removal of a class of VOCs, especially the complete oxidation of benzene, $n$-hexane, ethyl acetate, and mesitylene. As depicted in Fig. 11, the $T_{90}$ values for the catalytic oxidation of benzene, ethyl acetate, $n$-hexane, and mesitylene are 216, 331, 271, and $200{ }^{\circ} \mathrm{C}$, respectively. Notably, high temperature is required for ethyl acetate conversion at $90 \%$ due to its strong structural stability ${ }^{[39-40]}$. These results show a broad scope toward catalytic combustion involving troublesome organic compounds over Pt/ATO-P and indicate that the Pt/ATO-P catalysts can provide a new insight for the oxidation of VOCs.

\section{Conclusions}

In summary, we successfully fabricated the amorphous mesoporous phosphated $\mathrm{TiO}_{2}$ supported platinum catalysts for efficient removal of volatile organic compounds. The electronic modifications of supported Pt nanoparticles for the underlying amorphous ATO-P material and Pt loading for the whole catalyst were systematically investigated. The phosphorus dopant played an important role for stabilizing the inflated $\mathrm{Ti}-\mathrm{O}-\mathrm{P}$ frameworks as well as the electronic structure of Pt species. Compared with pristine $\mathrm{TiO}_{2}$, ATO-P with high specific surface area showed significant enhancement for Pt/ATO-P samples for catalytic overall oxidation of toluene under practical conditions. The performance of the engineered Pt/ATO-P for toluene combustion was superior to the reference $\mathrm{Pt} / \mathrm{TiO}_{2}$ and comparable with the state-of-the-art catalysts. Additionally, Pt/ATO-P catalyst exhibited excellent stability for toluene oxidation removal under a relatively mild thermal process and could be potentially applied in a broad scope of VOCs. The present work is expected to make a significant contribution on the new application of amorphous mesoporous phosphated material in VOCs removal.

\section{Supporting Materials}

Supporting Materials related to this article can be found at https://doi.org/10.15541/jim20190154.

\section{References:}

[1] XIE S H, LIU Y X, DENG J G, et al. Insights into the active sites of ordered mesoporous cobalt oxide catalysts for the total oxidation of o-xylene. Journal of Catalysis, 2017, 352: 282-292.

[2] GENUINO H C, DHARMARATHNA S, NJAGI E C, et al. Gas-phase total oxidation of benzene, toluene, ethylbenzene, and xylenes using shape-selective manganese oxide and copper manganese oxide catalysts. Journal of Physical Chemistry C, 2012, 116(22): 12066-12078.

[3] SIHAIB Z, PULEO F, GARCIA-VARGAS J M, et al. Manganese oxide-based catalysts for toluene oxidation. Applied Catalysis B: Environmental, 2017, 209(15): 689-700. 
[4] ROKICIŃSKA A, DROZDEK M, DUDEK B, et al. Cobaltcontaining BEA zeolite for catalytic combustion of toluene. $A p$ plied Catalysis B: Environmental, 2017, 212: 59-67.

[5] SANTOS V P, PEREIRA M F R, ÓRFÃO J J M, et al. The role of lattice oxygen on the activity of manganese oxides towards the oxidation of volatile organic compounds. Applied Catalysis B: Environmental, 2010, 99(1/2): 353-363.

[6] ŠULIGOJ A, ŠTANGAR U L, RISTIĆ A, et al. $\mathrm{TiO}_{2}-\mathrm{SiO}_{2}$ films from organic-free colloidal $\mathrm{TiO}_{2}$ anatase nanoparticles as photocatalyst for removal of volatile organic compounds from indoor air. Applied Catalysis B: Environmental, 2016, 184: 119-131.

[7] QIAN X F, YUE D T, TIAN Z Y, et al. Carbon quantum dots decorated $\mathrm{Bi}_{2} \mathrm{WO}_{6}$ nanocomposite with enhanced photocatalytic oxidation activity for VOCs. Applied Catalysis B: Environmental, 2016, 193: 16-21.

[8] CHEN J, CHEN X, XU W J, et al. Homogeneous introduction of $\mathrm{CeO}_{y}$ into $\mathrm{MnO}_{x}$-based catalyst for oxidation of aromatic VOCs. Applied Catalysis B: Environmental, 2018, 224: 825-835.

[9] YANG H G, DENG J G, LIU Y X, et al. Preparation and catalytic performance of $\mathrm{Ag}, \mathrm{Au}, \mathrm{Pd}$ or $\mathrm{Pt}$ nanoparticles supported on $3 \mathrm{DOM} \mathrm{CeO}{ }_{2}-\mathrm{Al}_{2} \mathrm{O}_{3}$ for toluene oxidation. Journal of Molecular Catalysis A: Chemical, 2016, 414: 9-18.

[10] PENG R S, SUN X B, LI S J, et al. Shape effect of $\mathrm{Pt} / \mathrm{CeO}_{2}$ catalysts on the catalytic oxidation of toluene. Chemical Engineering Journal, 2016, 306: 1234-1246.

[11] ALGHAMDI A O, JEDIDI A, AZIZ S G, et al. Theoretical insights into dehydrogenative chemisorption of alkylaromatics on $\operatorname{Pt}(100)$ and $\mathrm{Ni}(100)$. Journal of Catalysis, 2018, 363: 197-203.

[12] ZHANG Z X, JIANG Z, SHANGGUAN W F. Low-temperature catalysis for VOCs removal in technology and application: a state-of-the-art review. Catalysis Today, 2016, 264: 270-278.

[13] XIE S H, LIU Y X, DENG J G, et al. Effect of transition metal doping on the catalytic performance of $\mathrm{Au}-\mathrm{Pd} / 3 \mathrm{DOM} \mathrm{Mn}_{2} \mathrm{O}_{3}$ for the oxidation of methane and o-xylene. Applied Catalysis B: Environmental, 2017, 206: 221-232.

[14] SANTOS V P, CARABINEIRO S A C, TAVARES P B, et al. Oxidation of $\mathrm{CO}$, ethanol and toluene over $\mathrm{TiO}_{2}$ supported noble metal catalysts. Applied Catalysis B: Environmental, 2010, 99(1/2): 198-205.

[15] FU X R, LIU Y, YAO W Y, et al. One-step synthesis of bimetallic $\mathrm{Pt}-\mathrm{Pd} / \mathrm{MCM}-41$ mesoporous materials with superior catalytic performance for toluene oxidation. Catalysis Communications, 2016, 83: $22-26$.

[16] YIN G H, HUANG X Y, CHEN T Y, et al. Hydrogenated blue titania for efficient solar to chemical conversions: preparation, characterization, and reaction mechanism of $\mathrm{CO}_{2}$ reduction. $A C S \mathrm{Ca}$ talysis, 2018, 8(2): 1009-1017.

[17] WU D W, ZHANG Q L, LIN T, et al. Effect of Fe on the selective catalytic reduction of $\mathrm{NO}$ by $\mathrm{NH}_{3}$ at low temperature over $\mathrm{Mn} / \mathrm{CeO}_{2}-\mathrm{TiO}_{2}$ catalyst. Journal of Inorganic Materials, 2012, 27(5): 495-500.

[18] YU W W, ZHANG Q H, SHI G Y, et al. Preparation of Pt-loaded $\mathrm{TiO}_{2}$ nanotubes/nanocrystals composite photocatalysts and their photocatalytic properties. Journal of Inorganic Materials, 2011, 26(7): 747-752.

[19] COMOTTI M, LI W C, SPLIETHOFF B, et al. Support effect in high activity gold catalysts for $\mathrm{CO}$ oxidation. Journal of the American Chemical Society, 2006, 128(3): 917-924.

[20] LEE J S, PARK G S, LEE H I, et al. Ketjenblack carbon supported amorphous manganese oxides nanowires as highly efficient electrocatalyst for oxygen reduction reaction in alkaline solutions. $\mathrm{Na}$ no Letters, 2011, 11(12): 5362-5366.
[21] ZHENG Y L, WANG W Z, JIANG D, et al. Amorphous $\mathrm{MnO}_{x}$ modified $\mathrm{Co}_{3} \mathrm{O}_{4}$ for formaldehyde oxidation: improved low-temperature catalytic and photothermocatalytic activity. Chemical Engineering Journal, 2016, 284: 21-27.

[22] GUO Y Y, ZHANG S, MU W T, et al. Methanol total oxidation as model reaction for the effects of different $\mathrm{Pd}$ content on $\mathrm{Pd}-\mathrm{Pt} / \mathrm{CeO}_{2}-\mathrm{Al}_{2} \mathrm{O}_{3}-\mathrm{TiO}_{2}$ catalysts. Molecular Catalysis, 2017, 429: $18-26$.

[23] CLEARFIELD A, THAKUR D S. Zirconium and titanium phosphates as catalysts: a review. Applied Catalysis, 1986, 26: 1-26.

[24] YU J C, ZHANG L Z, ZHENG Z, et al. Synthesis and characterization of phosphated mesoporous titanium dioxide with high photocatalytic activity. Chemistry of Materials, 2003, 15(11): 2280-2286.

[25] KÖRÖSI L, OSZKÓ A, GALBÁCS G, et al. Structural properties and photocatalytic behaviour of phosphate-modified nanocrystalline titania films. Applied Catalysis B: Environmental, 2007, 77(1/2): 175-183.

[26] KÖRÖSI L, PAPP S, BERTÓTI I, et al. Surface and bulk composition, structure, and photocatalytic activity of phosphate-modified $\mathrm{TiO}_{2}$. Chemistry of Materials, 2007, 19(19): 4811-4819.

[27] MASLOVA M V, RUSANOVA D, NAYDENOV V, et al. Synthesis, characterization, and sorption properties of amorphous titanium phosphate and silica-modified titanium phosphates. Inorganic Chemistry, 2008, 47(23): 11351-11360.

[28] ZHU Y L, ZHOU W, SUNARSO J, et al. Phosphorus-doped perovskite oxide as highly efficient water oxidation electrocatalyst in alkaline solution. Advanced Functional Materials, 2016, 26(32): $5862-5872$.

[29] HEO Y W, PARK S J, IP K, et al. Transport properties of phosphorus-doped ZnO thin films. Applied Physics Letters, 2003, 83(6): $1128-1130$

[30] YIN G H, BI Q Y, ZHAO W, et al. Efficient conversion of $\mathrm{CO}_{2}$ to methane photocatalyzed by conductive black titania. ChemCatChem, 2017, 9(23): 4389-4396.

[31] PLUMEJEAU S, RIVALLIN M, BROSILLON S, et al. The reductive dehydration of cellulose by solid/gas reaction with $\mathrm{TiCl}_{4}$ at low temperature: a cheap, simple, and green process for preparing anatase nanoplates and $\mathrm{TiO}_{2} / \mathrm{C}$ composites. Chemistry-A European Journal, 2016, 22(48): 17262-17268.

[32] REN T Z, YUAN Z Y, AZIOUNE A, et al. Tailoring the porous hierarchy of titanium phosphates. Langmuir, 2006, 22(8): 3886-3894.

[33] YOSHIDA H, YAZAWA Y, HATTORI T. Effects of support and additive on oxidation state and activity of Pt catalyst in propane combustion. Catalysis Today, 2003, 87(1-4): 19-28.

[34] TIERNAN M J, FINLAYSON O E. Effects of ceria on the combustion activity and surface properties of $\mathrm{Pt} / \mathrm{Al}_{2} \mathrm{O}_{3}$ catalysts. $A p$ plied Catalysis B: Environmental, 1998, 19(1): 23-25.

[35] LYKHACH Y, FAISAL F, SKÁLA T, et al. Interplay between the metal-support interaction and stability in $\mathrm{Pt} / \mathrm{Co}_{3} \mathrm{O}_{4}$ (111) model catalysts. Journal of Materials Chemistry A, 2018, 6: 23078-23086.

[36] ZHANG C B, HE H, TANAKA KI. Catalytic performance and mechanism of a Pt/TiO 2 catalyst for the oxidation of formaldehyde at room temperature. Applied Catalysis B: Environmental, 2006, 65: 37-43.

[37] RAHMANI F, HAGHIGHI M, ESTIFAEE P. Synthesis and characterization of $\mathrm{Pt} / \mathrm{Al}_{2} \mathrm{O}_{3}-\mathrm{CeO}_{2}$ nanocatalyst used for toluene abatement from waste gas streams at low temperature: conventional $v s$. plasma-ultrasound hybrid synthesis methods. Microporous and Mesoporous Materials, 2014, 185(1): 213-223.

[38] CHEN C Y, CHEN F, ZHANG L, et al. Importance of platinum 
particle size for complete oxidation of toluene over Pt/ZSM-5 catalysts. Chemical Communications, 2015, 51: 5936-5938.

[39] LI S M, HAO Q L, ZHAO R Z, et al. Highly efficient catalytic removal of ethyl acetate over Ce/Zr promoted copper/ZSM-5 cata- lysts. Chemical Engineering Journal, 2016, 285: 536-543.

[40] CARABINEIRO S A C, CHEN X, MARTYNYUK O, et al. Gold supported on metal oxides for volatile organic compounds total oxidation. Catalysis Today, 2015, 244: 103-114.

\title{
掺磷非晶氧化钛负载铂用于高效催化氧化 挥发性有机化合物
}

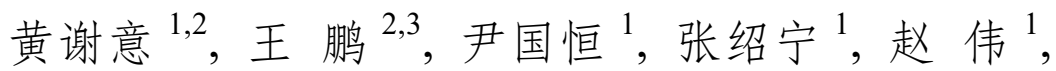 \\ 王东 ${ }^{1}$, 毕庆员 ${ }^{1}$, 黄富强 ${ }^{1,3,4}$
}

(1. 中国科学院 上海硅酸盐研究所, 高性能陶瓷和超微结构国家重点实验室, 上海 200050; 2. 中国科学院大学, 北京 $100049 ; 3$. 上海科技大学 物理科学与技术学院, 上海 $200050 ; 4$. 北京大学 化学与分子工程学院, 稀土材料 化学及应用国家重点实验室, 北京 100871)

摘 要: 高活性催化剂是挥发性有机化合物(VOCs)催化氧化消除的关键因素。本研究通过简单的共沉淀法成功制备 了具有高比表面积的非晶介孔磷掺杂氧化钛负载铂催化剂(Pt/ATO-P)。通过 P 掺杂, 既可获得非晶介孔结构, 又可 获得高 ATO-P 比表面积(可达 $278.9 \mathrm{~m}^{2} \cdot \mathrm{g}^{-1}$ )。非晶介孔 Pt/ATO-P 催化剂显示出优异的 VOCs 催化氧化性能和良好 的热稳定性。 $\mathrm{Pt} /$ ATO-P 样品在空速为 $36000 \mathrm{~mL} \cdot \mathrm{h}^{-1} \cdot \mathrm{g}^{-1}$ 、甲苯浓度为 $10000 \mathrm{~mL} \cdot \mathrm{m}^{-3}$ 的反应条件下, 对甲苯催化氧 化的 $T_{50}$ 和 $T_{90}$ (实现 $50 \%$ 和 $90 \%$ 转化率所需的温度)分别为 $130{ }^{\circ} \mathrm{C}$ 和 $140{ }^{\circ} \mathrm{C}$, 明显优于无磷催化剂 $\mathrm{Pt} / \mathrm{TiO}_{2}$ 。这些发 现可以为拓展非晶介孔磷化材料在环境净化和能源转化等领域的应用提供重要参考。

关 键 词: 非晶介孔材料; 磷掺杂非晶氧化钛; 铂纳米颗粒; 甲苯催化氧化; VOCs 消除 中图分类号: O782 文献标识码: A 
Supporting Materials:

\title{
Removal of Volatile Organic Compounds Driven by Platinum Supported on Amorphous Phosphated Titanium Oxide
}

\author{
HUANG Xie-Yii ${ }^{1,2}$, WANG Peng ${ }^{2,3}$, YIN Guo-Heng ${ }^{1}$, ZHANG Shao-Ning ${ }^{1}$, \\ ZHAO Wei ${ }^{1}$, WANG Dong ${ }^{1}$, BI Qing-Yuan ${ }^{1}$, HUANG Fu-Qiang ${ }^{1,3,4}$
}

(1. State Key Laboratory of High Performance Ceramics and Superfine Microstructure, Shanghai Institute of Ceramics, Chinese Academy of Sciences, Shanghai 200050, China; 2. University of Chinese Academy of Sciences, Beijing 100049, China; 3. School of Physical Science and Technology, ShanghaiTech University, Shanghai 200031, China; 4. State Key Laboratory of Rare Earth Materials Chemistry and Applications, College of Chemistry and Molecular Engineering, Peking University, Beijing 100871, China)
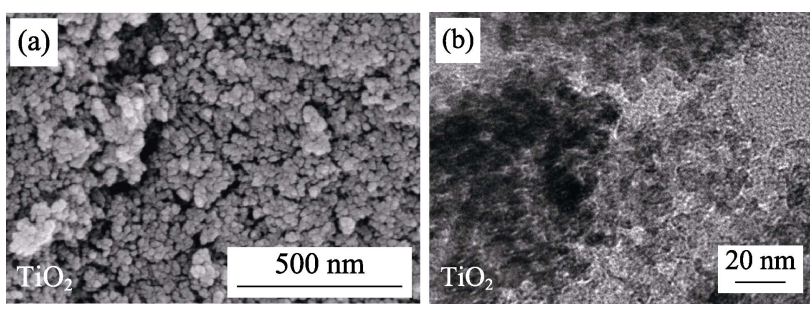

Fig. S1 SEM (a) and HRTEM (b) images of $\mathrm{TiO}_{2}$

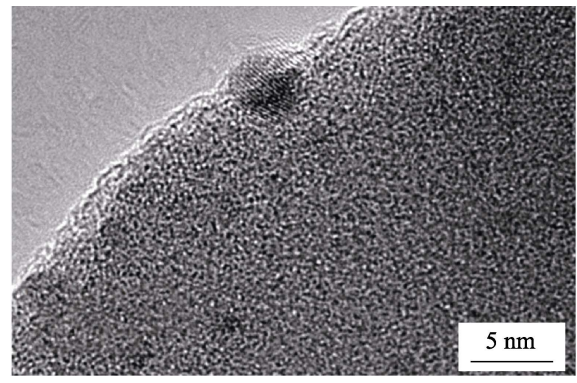

Fig. S2 HRTEM image of Pt/ATO-P

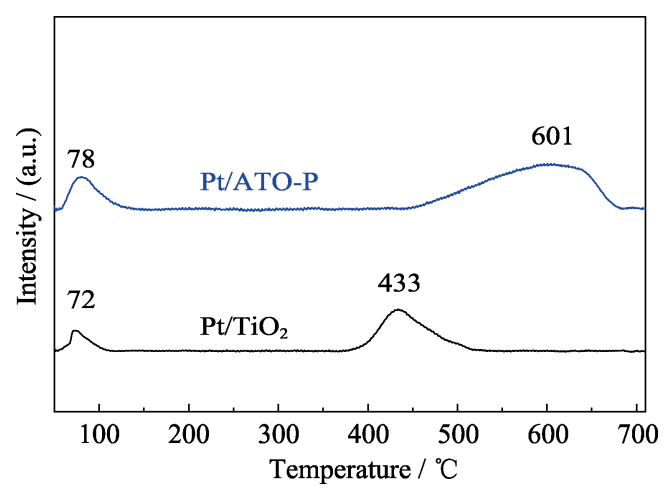

Fig. S3 $\mathrm{H}_{2}$-TPR profiles of $\mathrm{Pt} / \mathrm{TiO}_{2}$ and $\mathrm{Pt} / \mathrm{ATO}-\mathrm{P}$ samples
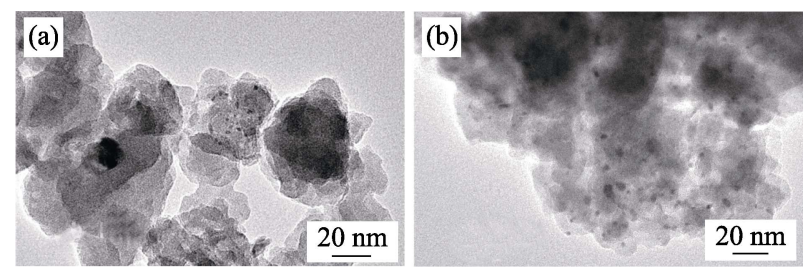

Fig. S4 TEM images of $0.5 \mathrm{wt} \%$ Pt/ATO-P (a) and $2 \mathrm{wt} \%$ Pt/ATO-P (b)

For the catalyst with low loading of $0.5 \mathrm{wt} \%$, there are few Pt nanoparticles in the ATO-P supports. By contract, the Pt particles are larger than that with loading of $1 \mathrm{wt} \%$ when the loading up to $2 \mathrm{wt} \%$
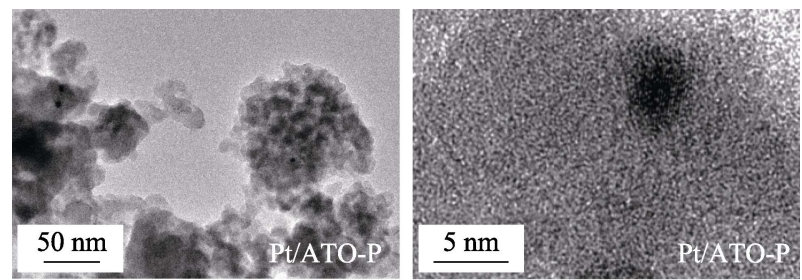

Fig. S5 TEM (a) and HRTEM (b) images of the used Pt/ATO-P catalyst

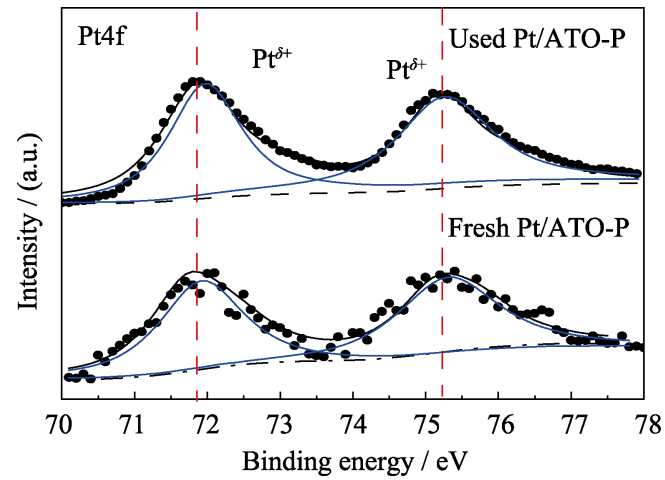

Fig. S6 XPS Pt 4f spectra of the fresh and the used Pt/ATO-P catalysts 